University of Nebraska - Lincoln

DigitalCommons@University of Nebraska - Lincoln

Great Plains Research: A Journal of Natural and

Social Sciences

Great Plains Studies, Center for

February 1995

\title{
Lost Harvests: Prairie Indian Reserve Farmers and Government Policy
}

Todd Kerstetter

University of Nebraska - Lincoln

Follow this and additional works at: https://digitalcommons.unl.edu/greatplainsresearch

Part of the Other International and Area Studies Commons

Kerstetter, Todd, "Lost Harvests: Prairie Indian Reserve Farmers and Government Policy" (1995). Great Plains Research: A Journal of Natural and Social Sciences. 184.

https://digitalcommons.unl.edu/greatplainsresearch/184

This Article is brought to you for free and open access by the Great Plains Studies, Center for at DigitalCommons@University of Nebraska - Lincoln. It has been accepted for inclusion in Great Plains Research: A Journal of Natural and Social Sciences by an authorized administrator of DigitalCommons@University of Nebraska Lincoln. 
Lost Harvests: Prairie Indian Reserve Farmers and Government Policy. Sarah Carter. Montreal: McGill-Queen's University Press, 1990. xi+323 pp. Maps, photos, and references. \$US39.95 cloth, (ISBN 0-7735-0755-8).

Until recently, prevailing wisdom in academic circles held that nomadic, buffalo hunting tribes on the Great Plains resisted all efforts to make them farmers. According to the old school, sedentary, regimented agricultural life on a reservation violated these noble hunters' culture. Sarah Carter says that the old school was dead wrong. Carter, a Canada Research Fellow with the Department of History and Rupert's Land Research Centre at the University of Winnipeg, argues that during the last quarter of the nineteenth century Indians in Canada's prairie provinces stood ready and willing to adopt an agricultural lifestyle. The Canadian government, however, despite its proclaimed desire to make farmers of reservation Indians, enacted policies that actually inhibited successful Indian agriculture and contributed to Indians turning away from farming. Thus she seeks to revise the old interpretation that the prairie province tribes held agriculture in contempt and resisted the government's best efforts to make them self-sufficient farmers.

Carter surveys the history of Plains Indian farming and of government Indian policies through the 1870 s. She points out that Plains Indian agricul- 
ture far predated its horse culture and that the tribes under considerationPlains Cree, Assiniboine, Salteaux, and Dakota-not only knew of agriculture, but also had in many cases practiced it. By the 1870 s, she argues, Plains tribes recognized the need to diversify their economy in the face of rapidly declining buffalo herds and many prepared to embrace agriculture. Despite their experience and willingness, however, they needed government assistance to make the transition.

But thanks to bureaucratic bungling, greed, and other factors, the government failed to deliver. For example, government surveyors recommended Indian reservations be located out of the path of the planned Canadian Pacific Railroad and expected settlement by European-Americans. Unfortunately for the Indians, the railroad's planned route ran through the heart of the best farmland. Locating the reservation away from the railroad, then, deprived them of both good land and access to markets.

Despite these handicaps, many Plains tribes tried to farm. But when they encountered difficulties and asked the government for help, the bureaucracy either turned a deaf ear or reacted ineptly or too slowly. When the government's initial ad hoc Indian policies failed, it responded with new policies which also served to frustrate Indian agricultural efforts. Under the home farm system, the government supplied advisors to teach farming and to supervise the distribution of supplies. Corrupt and ignorant-of both Plains farming and Indian culture-advisors doomed this approach to failure by the mid-1880s.

By the late 1880 s and early 1890 s, reserve Indians had learned enough commercial agricultural skills to compete with neighboring EuropeanAmerican farmers. Carter argues that to maintain European-American prosperity the government enacted twin policies to limit Indian agricultural productivity. First, the government pushed for allotment in severalty, breaking reserves into small, individual farms. Second, the government urged Indians to emulate peasant farming techniques by having each family produce only to meet its needs, not to produce a surplus for the market. To encourage peasant farming, the government banned Indians from using machinery. Indians, supposedly, needed to advance slowly from their tribal society to peasant farming to commercial farming lest they violate the rules of social evolution and suffer irreparable damage. Meanwhile, government policy hamstrung Indian agriculture.

Although the subtitle suggests merely a policy study, the book contains enlightening ethnographic information about reserve farming. For instance, Carter briefly discusses skills such as milking and butter-making that re- 
serve women learned from government agents or their wives. Carter rather dubiously uses the fact that Indian women learned these skills and that young Indian women learned housewifery skills at boarding schools to show Indian acceptance and support for the transition to farm life.

Carter researched Lost Harvests thoroughly, although, as is often the case in Indian history written for this time period, the Indian voice is hard to find. She also argues convincingly and in a readable style that prairie province Indians wanted to farm and that the government not only failed to help them, but actually hindered them. Todd Kerstetter, Department of History, University of Nebraska-Lincoln. 